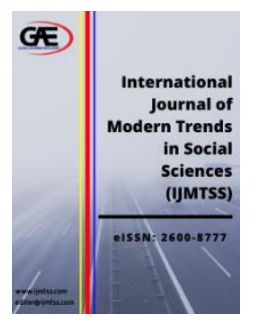

\author{
INTERNATIONAL JOURNAL OF \\ MODERN TRENDS IN \\ SOCIAL SCIENCES \\ (IJMTSS) \\ www.ijmtss.com
}

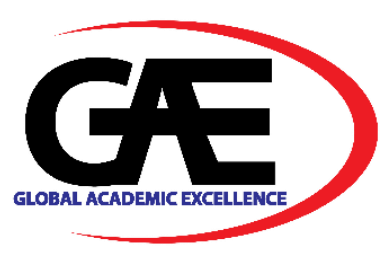

\title{
A REVIEW OF PURCHASE INTENTION ON INSTAGRAM AMONG UNIVERSITI TEKNOLOGI MALAYSIA LOCAL UNDERGRADUATES' STUDENTS
}

Nur Hafizah Zulkarnain ${ }^{1}$, Sabrinah Adam ${ }^{2 *}$

1 Azman Hashim International Business School, Universiti Teknologi Malaysia (UTM), Malaysia Email: nurhafizahzulkarnain@graduate.utm.my

2 Azman Hashim International Business School, Universiti Teknologi Malaysia (UTM), Malaysia

Email: sabrinah@utm.my

* Corresponding Author

\section{Article Info:}

\section{Article history:}

Received date: 20.02 .2021

Revised date: 18.03 .2021

Accepted date: 28.03.2021

Published date: 31.03 .2021

To cite this document:

Zulkarnain, N. H., \& Adam, S. (2021).

A Review of Purchase Intention on Instagram Among Universiti Teknologi Malaysia Local Undergraduates' Students. International Journal of Modern Trends in Social Sciences, 4 (15), 114120.

DOI: $10.35631 /$ IJMTSS.4150010

This work is licensed under CC BY 4.0

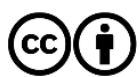

\begin{abstract}
:
The aim of this study to identify the conceptual framework of purchase intention on Instagram among local undergraduates' students of Universiti Teknologi Malaysia (UTM). The variables consist of Perceived Usefulness (PU), Perceived Ease of Use (PEOU), and Web content as the independent variable, and purchase intention is the dependent variable. This study adopted a quantitative approach using IBM SPSS version 26 . The survey was conducted on local undergraduates' students at Universiti Teknologi Malaysia. The conceptual framework has been developed in this study. The expected findings show there is a positive relationship between Perceived Usefulness (PU), Perceived Ease of Use (PEOU), Web content and purchase intention.
\end{abstract}

Keywords:

Perceived Usefulness, Perceived Ease of Use, Web content, Purchase intention, Instagram

\section{Introduction}

Nowadays, the society getting limitless and wall-less. The way and concept of trading and doing business nowadays have been shifted to online-based relying on Internet connection, big 
data centre, and cyber-space systems that uphold the emerging of e-business trends. On the other hand, e-business defined as several other business processes that uphold the transaction of buy and sell products and services on the internet rather than e-commerce, which only covers the commercial transaction on the internet. Thus, e-business cover beyond the commercial transaction on the internet; it also includes its business stakeholders such as the supplier, external and internal customer, etc. E-business is the host of e-commerce. E-commerce transaction cannot take place without e-business (Dayton, 2020).

Consequently, the rising trend of online shopping among social media users has brought ebusiness concepts to a new paradigm since web-based life has become a piece of individuals' life nowadays, as the impact of the internet and technological advancement. Instagram is very innovative in introducing many new features such as story-integration, which provided a selfdestruction story within 24 hours, which also allows users to edit their pictures and video clips with so many interesting effects. The user can be creative by creating and adding their Graphic Interchange Format (GIF) and stickers, which gives them freedom and have full control over their Instagram story and feed. Instagram also has transformed the traditional ways of communication toward picture-messaging apps that have created new forms of online communication. Thus, the layout of Instagram also is very mobile-friendly, which you can access it across devices such as a personal computer, tablet, or either smartphone (Shah, 2018).

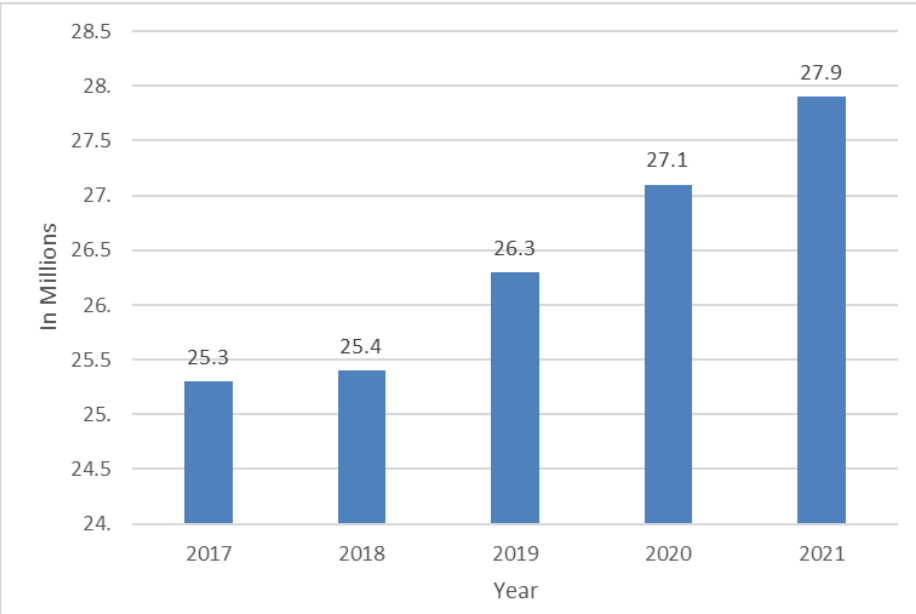

Source: (Statista, 2020)

Figure 1: Malaysia's internet users from 2017 to 2021 (in millions)

Figure 1 shows Malaysia's significant increase every year by at least 10 million per year, which consist of about $84 \%$ of Malaysia total population as at March 2020 have access to the Internet and own at least one device to navigate social media (United Nations, 2020).

Table 1: Photo-sharing Social Media Users in Malaysia by December 2019

Source: (Statcounter)

\begin{tabular}{|l|c|}
\hline Types of Photo-sharing Social Media & Percentage (\%) \\
\hline Pinterest & 6.16 \\
\hline Instagram & 5.59 \\
\hline Tumblr & 0.3 \\
\hline
\end{tabular}




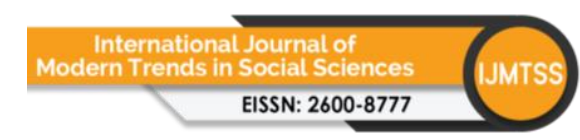

Volume 4 Issue 15 (March 2021) PP. 114-120

DOI 10.35631/IJMTSS.4150010

Table 1 shows the number of social media apps users among Malaysians in December 2019. Even though Pinterest is the highest used in photo-sharing sites, but Pinterest has the least userfriendly features for people to buy on the websites. Pinterest mainly provides ideas for fashion, home décor, DIY gifts, etc. Unlike Instagram, initially allows people to share their life journey dedicated through photos. Additionally, Instagram also has business features that enable people to become a seller and provides many key features such as analytics, promotion, etc., which makes it the most used photo-sharing sites for e-business compared with Pinterest and Tumblr (Kim, Seely and Jung, 2017).

The number of Instagram users worldwide is increasing blatantly by increasing 100 million Instagram users every year. A massive step for Instagram as the number of users dominantly increase by an enormous gap between 2017 and 2018, which is 200 million differences (Statista, 2019). Hence, with more than 2.77 billion daily social media users, the marketing department wants to further research in a manner to comprehend more about customer conduct. Thus, the total of the Instagram user has been over 1 billion per month (Hootsuite, 2019).

\section{Problem Statement}

The e-business sectors are growing fast in Malaysia. As said by Melão (2009), e-business not only involves the pay and trading process but also includes internally such as employees, and external stakeholders consist of customers, suppliers, etc. Many small-medium enterprises (SME) have shift from physical store to online store to reach more and wider range of customer. Since many SME adapted Instagram as one of their online platforms, there is a need to conduct a comprehensive research to study the factors that would influence intention to purchase on Instagram.

Above all, most of previous study generally did not solely focused on e- business platform to identify the factors of purchase intention. As example, study by Haque et al. (2015); Mou et al. (2019); Zhu et al. (2019), did not specifically focused on certain e-business platform i.e., Instagram, which did not reflect the factor that determine purchase intention on actual course.

Moreover, the research in this context here in Malaysia, which examines the different factors affecting purchase intention, conceptual and calculated study is absent in the e-business context. Although numerous examinations have proved the Technology Acceptance Model (TAM) in the contexture of e-business i.e., Cho and Sagynov (2015), there is also the inadequacy of research on how Perceived Usefulness (PU), Perceived Ease of Use (PEOU) and Web content affect purchase intention in Malaysia by using Instagram as e-business platforms. Plus, it is consequential to explore factors that shaping purchase intention in an e-business context. In Malaysia, there is no empirical study among generation Z, precisely on Universiti Teknologi Malaysia (UTM) local undergraduates, to investigate the factor that affects intention to purchase on Instagram (Kulathunga, 2019).

The following section will discuss on the development of conceptual framework between perceived usefulness (PU), perceived ease of use (PEOU), web content and purchase intention on Instagram. Next sections, followed by a brief discussion of the research methods. This paper concludes with the expected findings of the present study. 


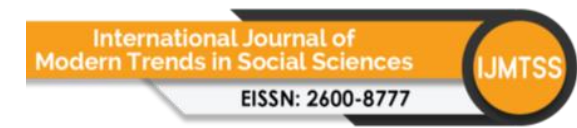

Volume 4 Issue 15 (March 2021) PP. 114-120

DOI 10.35631/IJMTSS.4150010

\section{Literature Review}

\section{Perceived Usefulness (PU)}

In this context of the study, PU is one of the indicators to see to what extent a customer will use the application or system that can perform effectively and efficiently. (Delafrooz et al., 2011). Moreover, PU is used to identify users of e-business on the subjective valuation of the system to perform a specific task (Gefen, Karahana, and Straub, 2003). On the other hand, PU has relatively had a positive influence toward actual internet usage, since Internet has embarked its recent technology and bring convenience online shopping experience, the online shopping behaviour will also turn out positive (Anisur et al., 2016). Thus, when the customer perceives a high level of usefulness and has excellent experience, they tend to be more satisfied when using e-business platform (Yusof, 2015). To add, PU also gives eloquent benefits towards the technology users when they were using e-business platform (Nistah, Sura, Yusof, and Lee 2019).

\section{Perceived Ease of Use (PEOU)}

According to Cho and Son (2019), the customers will perceive Instagram as easy to use if they feel more connected with the seller, which will drive them to adapt Instagram as an e-business platform further. Consequently, when the user has a positive experience when using Instagram to shop online, it will increase the probability of the intention to purchase (Al-Adwan, 2019). Another research by Othman, et.al, (2019) found that PEOU has been a critical factor shaping Instagram's adoption on the e-business site. Plus, PEOU also has been proven can influence customer intention to purchase on Instagram (Moslehpour, Pham, Wong and Bilgiçli, 2018). In addition, other scholars also supported that PEOU has direct influence toward the system usage, depending on the context of the technology used as in this context, the e-business platform (Anisur et al., 2016).

\section{Web Content}

Information is anything accessible to the customers, especially in terms of Instagram content and information. The information displayed needs to be accurate, including product or service description, seller contact information, payment, shipment details, and review of past customers. These factors are crucial, which are very influential toward user perception when using Instagram to shop (Zhang, $\mathrm{Xu}, \mathrm{Zhao}$, and $\mathrm{Yu}, 2018$ ). Incomplete information regarding the product sold will affect purpose of the user to spend on Instagram (Samira et al., 2017) and affect the customer experience in a negative way (Sykes and Venkatesh, 2017). Instead, when the customer has incomplete information on hand, they will reach the seller and their friend to seek more relevant information to increase the intention to purchase (Suh et al., 2017). Thus, another study by Lu, Guo, Lu, and Gupta (2018) showed that the communication between the customer and seller most likely failed if the details presented is incomplete from the customer's point of view.

\section{Purchase Intention}

Deimling et al. (2016) regarded that information on specific products has a very close relationship with purchase intention whereby the source of information would influence customers to buy without disregarding current and future occurrences. Thus, another scholar also defines purchase intention as a customer's transaction behaviour after assessing the product as a whole and react emotionally toward brand attitudes, etc. (Chung et al., 2016) as Jarvis et al. (2016) specified purchase intention as to how customer's intention subjectively pick a particular product or brand - supported by Rajaguru (2016) theory indicated purchase Copyright (C) GLOBAL ACADEMIC EXCELLENCE (M) SDN BHD - All rights reserved 
intention as customer need their judgment in judging the current and future situation whether to repurchase the service or not.

\section{Conceptual Framework}

The conceptual framework of this study has been developed as follows;

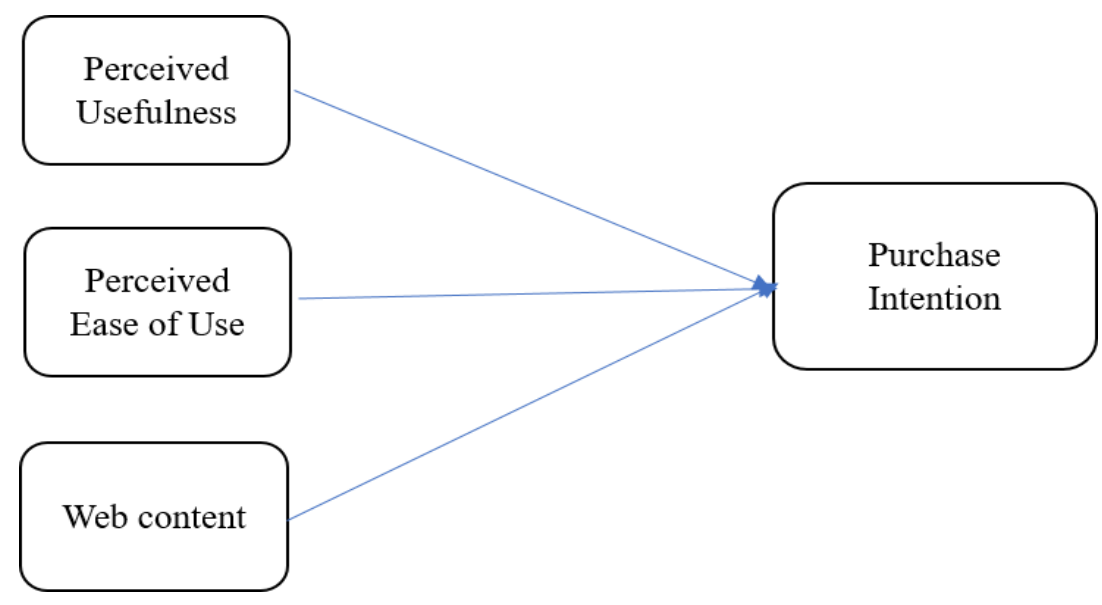

\section{Figure 2: Conceptual Framework Of Factors That Affect Purchase Intention On Instagram Among UTM Local Undergraduates' Students}

\section{Relationship between Perceived Usefulness (PU) and Purchase Intention}

Buaprommee and Polyorat (2016) have validated PU has an eloquent impact on the purchase intention of traceable meat that included in the food supply sector. Another significant study that is within the Malaysia context, PU has bound to be impactful toward customer's purchase intention in e-business context (Hew et al., 2016). Consequently, Hypothesis 1 (H1) developed as follows.

H1: PU will positively influence purchase intention.

\section{Relationship between Perceived Ease of Use (PEOU) and Purchase Intention}

Earlier research by Renny et al. (2013) and Ngoc et al. (2019) has shown that PEOU has profound effect on website $\&$ purchase intention to purchase customers. This research, also supported by Othman et al. (2019), outlined that PEOU has a significant effect on the intention to buy in the e-business sense. PEOU proved to have a direct positive correlation toward the easiness of using e-business platforms. Hence, Hypothesis $2(\mathrm{H} 2)$ developed as follows.

H2: There is a positive effect of PEOU on purchase intention.

\section{Relationship between Web Content and Purchase Intention}

Study by Osburg et al. (2019), a high quality of facts and detail information regarding the product appears on the website have beneficial impact on intention to buy. On the other hand, another study by Cui, Jiang et al. (2019) in China showed that customer's intention to purchase indirectly affected by high quality and credibility of information on e- business platforms in the food safety industry. Therefore, Hypothesis 3 (H3) developed as follows.

H3: Web content will have a profound effect on intention to purchase. 


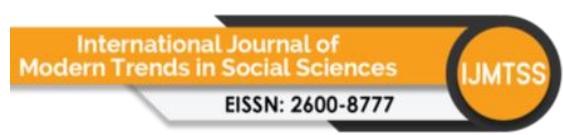

Volume 4 Issue 15 (March 2021) PP. 114-120 DOI 10.35631/IJMTSS.4150010

\section{Research Methodology}

The population of this study consists of local undergraduates of UTM Skudai Campus. A quantitative approach using self-administered questionnaire was adopted. Stratified sampling technique was adopted to distribute questionnaire to the local undergraduates of UTM. The data will be analysed using the Statistical Package for the Social Sciences (SPSS) version 26 to evaluate the purchase intention among students of local UTM undergraduates. Numerous data analysis sets will be used in this study such as analysis on reliability, descriptive analysis, t-test, one-way ANOVA, analysis of multicollinearity, and analysis of multiple regressions. The pilot test has been conducted on 30 respondents from local undergraduates' students from Azman Hashim International Business School (AHIBS) local undergraduates to test the reliability by using Google Form questionnaire and has collected 30 samples among Azman Hashim International Business School local undergraduates. Below is the table of each variable with each of their Cronbach's Alpha Value. All of the value shows more than 0.7.

\section{Findings}

The expected findings show there is a positive relationship between Perceived Usefulness (PU), Perceived Ease of Use (PEOU), Web content and purchase intention on Instagram among UTM local undergraduate students.

\section{Conclusion}

The conclusion, this study will benefit the small-medium enterprise (SME) to help them understand consumers' behaviour on Instagram to fully adapted and utilized Instagram application as e-business platform. This study also will help the SME to unlock their potential to further explore and construct effective strategies to reach the right customer, that eventually would boost their sales.

\section{References}

Al-Adwan, A. S. (2019). Revealing the influential factors driving social commerce adoption. Interdisciplinary Journal of Information, Knowledge, and Management, 14(1), 295324.

Anisur, M., Qi, X., \& Islam, T. (2016). Banking Access For The Poor: Adoption And Strategies In Rural Areas Of Bangladesh. Journal of Economic \& Financial Studies, 4(3), 1-10.

Cho, E., \& Son, J. (2019). The Effect Of Social Connectedness On Consumer Adoption Of Social Commerce In Apparel Shopping. Fashion and Textiles, 6(1), 1-14.

Chung, K. H., Yu, J. E., Kim, W. \& Shin, J. I. (2016). The antecedent and consequences of brand image in a low-priced cosmetic brand of South Korea: The moderating effect of gender. International Journal of Science and Technology, 9(2),175-184.

Delafrooz, N., Paim, L. H. \& Khatibi, A. (2011). Understanding Consumer's Internet Purchase Intention In Malaysia. African Journal of Business Management, 5(3), 2837-2846.

Gefen D., Elena K. \& Detmar W.S. (2003), Trust and TAM in Online Shopping: An integratedModel. MIS Quarterly, 27(1),51-90.

Haque, A., Anwar, N., Yasmin, F., Sarwar, A., Ibrahim, Z., \& Momen, A. (2015). Purchase Intention Of Foreign Products: A Study On Bangladeshi Consumer Perspective. Sage Open, 5(2), 392-399.

Jarvis D, Stoeckl N., \& Liu H. B. (2016). The Impact Of Economic, Social And Environmental Factors On Trip Satisfaction And The Likelihood Of Visitors Returning. Tourism Management, 52(1),1-18. 
Kim, D. H., Seely, N. K., \& Jung, J. H. (2017). Do you prefer, Pinterest or Instagram? The role of image-sharing SNSs and self-monitoring in enhancing ad effectiveness. Computers in Human Behavior, 70(1), 535-543.

Lu, Y., Guo, C., Lu, Y., \& Gupta, S. (2018). The Role Of Online Communication In Avoiding Perceived Restrictiveness Of Shopping Websites. Nankai Business Review International. 9(2), 143-161.

Moslehpour, M., Pham, K., Wong, K., \& Bilgiçli, İ. (2018). E-purchase intention of Taiwanese consumers: Sustainable mediation of perceived usefulness and perceived ease of use. Sustainability, 10(1), 234-238.

Melão, N. (2009). E-Business Processes And E-Business Process Modelling: A state-of- art overview. International Journal of Services Technology and Management, 11(3), 293322.

Nistah, N. M., Sura, S., Yusof, M. M., \& Lee, O. (2019). The effect of social feature quality on the social commerce system. International Journal of Advanced Computer Science and Applications, 10(7), 136-140.

Othman, A. K., Hassan, L. F. A., Hamzah, M. I., Razali, A. R., Saim, M. A. S., Ramli, $\quad$ M. S., \& Azhar, M. A. A. (2019). The Influence of Social Commerce Factors on Customer Intention to Purchase. Asian Themes in Social Sciences Research, 3(1), 1-10. Rajaguru, R. (2016). Role Of Value For Money And Service Quality On Behavioural Intention: A Study Of Full Service And Low-Cost Airlines. Journal of Air Transport Management, 53(1),114-122.

Shah, A. (2018, June 18). Instagram vs Facebook - Why Instagram Seems to be the Clear

Social Media Stats, Malaysia. (2020). Retrieved from Statcounter: https://gs.statcounter.com/social-media-stats/all/malaysia

Suh, A., Cheung, C. M., Ahuja, M., \& Wagner, C. (2017). Gamification in The Workplace: The Central Role of The Aesthetic Experience. Journal of Management Information Systems, 34(1), 268-305.

Sykes, T.A. \& Venkatesh, V. (2017). Research Article Explaining Post-Implementation Employee System Use And Job Performance: Impacts Of The Content And Source Of Social Network Ties. MIS Quarterly, 41(3), 917-936.

Winner. Retrieved https://www.business2community.com/instagram/instagram-vs-facebookwhy-instagram-seems-to-be-the-clear-winner-081557

Yusof, M. M. (2015). A Case Study Evaluation Of A Critical Care Information System Adoption Using The Socio-Technical And Fit Approach. International Journal of Medical Informatics, 84(7), 486-499.

Zhang, K. Z. K., Xu, H., Zhao, S. \&Yu, Y. (2018). Online Reviews And Impulse Buying Behaviour: The Role Of Browsing And Impulsiveness. Internet Research, 28(3), 522543. 